\title{
PERIPHERAL BLOOD HEMATOPOIETIC STEM CELL POOL IN INDIVIDUALS CHRONICALLY EXPOSED TO RADIATION OVER A LONG-TERM PERIOD
}

Kotikova $\mathrm{Al}^{1,2} \otimes$, Blinova $\mathrm{EA}^{1,2}$, Akleyev $\mathrm{AV}^{1,2}$

${ }^{1}$ Ural Research Center for Radiation Medicine, Chelyabinsk, Russia

${ }^{2}$ Chelyabinsk State University, Chelyabinsk, Russia

Changes in the peripheral blood cellular composition were observed in the long term period in the residents of the Techa riverside villages chronically exposed to radiation, which may be the consequence of structural and functional disorders in the pool of hematopoietic stem cells (HSC) and progenitor cells. Therefore, the study was aimed to quantify peripheral blood CD34+ cell pool in individuals chronically exposed to radiation over a long-term period. Sixty years after the onset of exposure, a total of 153 individuals were examined, who were divided into four groups: individuals exposed in utero and postnatally (the average postnatal absorbed dose was 570 mGy); individuals exposed only postnatally (the average postnatal absorbed dose was 790 mGy), and two comparison groups, in which the average postnatal absorbed dose to red bone marrow did not exceed $70 \mathrm{mGy}$. Absolute and relative peripheral blood CD34+ cell counts in chronically exposed individuals were assessed by flow cytometry. No changes in $\mathrm{CD} 34^{+}$cell counts compared to comparison group were revealed in the group of individuals exposed in utero and postnatally; no age-related changes were registered as well. However, a significant decline in absolute HSC and progenitor cell counts with increased absorbed dose to red bone marrow was observed. In the group of individuals exposed only postnatally, there was a significant increase in peripheral blood CD34+ cell counts compared to comparison group $(p=0.004$ for absolute cell count; $p=0.009$ for relative cell count), dose-dependent increase in peripheral blood HSC and precursor cell counts ( $p=0.02$ for absolute cell count; $p=0.03$ for relative cell count), along with age-related decline in these cells' counts ( $p=0.02$ for absolute cell count; $p=0.04$ for relative cell count).

Keywords: hematopoietic stem cells, chronic exposure, late effects, peripheral blood, flow cytometry

Funding: the study was carried out within the framework of the State assignment "Human Cell-Mediated Immunity During Realization of Chronic Radiation Exposure Late Effects" (code 27.002.20.800).

Author contribution: Kotikova Al — method design, laboratory tests, statistical analysis, manuscript writing; Blinova EA — method design, manuscript writing; Akleyev AV — study concept, scientific management.

Compliance with ethical standards: the study was approved by the Ethics Committee of Urals Research Center for Radiation Medicine (protocol № 3 dated July 20, 2021). All the subjects enrolled in the studies conducted by Laboratory of Molecular and Cellular Radiobiology of Urals Research Center for Radiation Medicine submitted the informed consent.

Correspondence should be addressed: Alisa I. Kotikova

Vorovskogo, 68, korp. A, Chelyabinsk, Russia, 454141; kotikovaalisa@gmail.com

Received: 21.07.2021 Accepted: 10.08.2021 Published online: 03.09.2021

DOI: 10.47183/mes.2021.023

\section{ПУЛ ГЕМОПОЭТИЧЕСКИХ СТВОЛОВЫХ КЛЕТОК В ПЕРИФЕРИЧЕСКОЙ КРОВИ ХРОНИЧЕСКИ ОБЛУЧЕННЫХ ЛИЦ В ОТДАЛЕННОМ ПЕРИОДЕ}

\author{
А. И. Котикова ${ }^{1,2}$, Е. А. Блинова ${ }^{1,2}$ А. В. Аклеев ${ }^{1,2}$ \\ ${ }^{1}$ Уральский научно-практический центр радиационной медицины Федерального медико-биологического агентства, Челябинск, Россия \\ 2 Челябинский государственный университет, Челябинск, Россия
}

\begin{abstract}
У жителей прибрежных сел реки Течи, подвергавшихся хроническому радиационному воздействию, отмечают изменения клеточного состава периферической крови в отдаленном периоде, что может быть следствием структурных и функциональных нарушений в пуле гемопоэтических стволовых клеток (ГСК) и клеток-предшественников. Целью работы было оценить количественные характеристики пула СDз4+-клеток периферической крови у хронически облученных лиц в отдаленном периоде. Через 60 лет после начала облучения обследовано 153 человека, которых разделили на четыре группы: лиц, облученных в период внутриутробного и постнатального развития (средняя поглощенная постнатальная доза составила 570 мГр); лиц, облученных только постнатально (средняя поглощенная постнатальная доза составила 790 мГр), а также две группы сравнения, в которых поглощенные постнатальные дозы облучения красного костного мозга (ККМ) не превышали 70 мГр. Оценку абсолютного и относительного количества CD34+-клеток в периферической крови у хронически облученных лиц проводили методом проточной цитометрии. В группе лиц, облученных в период внутриутробного и постнатального развития, не выявлено изменение количества CD34+-клеток относительно группы сравнения, возрастная зависимость также не зарегистрирована. При этом отмечено значимое снижение абсолютного количества ГСК и клеток-предшественников с увеличением дозы облучения KKM. В группе лиц, облученных только постнатально, обнаружено значимое увеличение показателей СDЗ4+-клеток периферической крови относительно группы сравнения (для абсолютного количества $p=0,004$; для относительного - $p=0,009$ ), отмечено дозозависимое увеличение ГСК и клеток-предшественников в периферической крови (для абсолютного количества $p=0,02 ;$ для относительного $p=0,03$ ), при этом зарегистрировано снижение данного типа клеток с возрастом (для абсолютного количества $p=0,02$, для относительного - $p=0,04$ ).
\end{abstract}

Ключевые слова: гемопоэтические стволовые клетки, хроническое облучение, отдаленные эффекты, периферическая кровь, проточная цитометрия Финансирование: исследование выполнено в рамках государственного задания «Состояние клеточного иммунитета человека в период реализации отдаленных эффектов хронического радиационного воздействия» (код 27.002.20.800).

Вклад авторов: А. И. Котикова - постановка методики, лабораторные исследования, статистическая обработка, написание текста статьи Е. А. Блинова - постановка методики, написание текста статьи; А. В. Аклеев - концепция исследования, научное руководство.

Соблюдение этических стандартов: исследование одобрено этическим комитетом ФГБУН УНПЦ РМ ФМБА России (протокол № 3 от 20 июля 2021 г.) Добровольное информированное согласие было получено от всех участников исследований, проводимых на базе лаборатории молекулярно-клеточной радиобиологии ФГБУН УНПЦ РМ ФМБА России.

$\triangle$ Для корреспонденции: Алиса Игоревна Котикова

ул. Воровского, д. 68, корп. А, г. Челябинск, Россия, 454141; kotikovaalisa@gmail.com

Статья получена: 21.07.2021 Статья принята к печати: 10.08.2021 Опубликована онлайн: 03.09.2021

DOI: $10.47183 /$ mes.2021.023 
More than 60 years ago, residents of the villages located along the Techa River, were chronically exposed to radiation due to liquid radioactive waste discharged by Mayak Production Association. Uneven radiation dose distribution in the body was the feature of the exposure. The highest radiation dose was received by red bone marrow due to accumulation of osteotropic ${ }^{90} \mathrm{Sr}$ in bone tissue [1]. As a result, there had been a stable decrease in peripheral blood platelet and leukocyte counts in exposed individuals in the early days with the dose rate exceeding 0.3-0.5 Gy/year [2].

Currently, restoration of the majority of immunocompetent cell pools is observed [3]. However, pro-inflammatory shift in the cytokine system together with steady decline in the neutrophil counts are registered against a background of normal G-CSF and GM-CSF [3, 4]. Structural and functional impairments in hematopoietic stem cell (HSC) pool and progenitor cells resulting from long-term radiation exposure to both HSCs and microenvironment cells can be the cause of the observed late effects on the immune system.

The study was aimed to quantify peripheral blood CD34+ cell pool in individuals chronically exposed to radiation over a long-term period.

\section{METHODS}

A total of 153 patients of the Ural Research Center for Radiation Medicine clinical department were enrolled. Inclusion criteria: residence in the villages located along the Techa River in 1950-1960; availability of calculated absorbed dose to red bone marrow, thymus and peripheral lymphoid organs [5]; no diagnostic or therapeutic radiation exposure for a period of 6 months before the study; no history of cancer, autoimmune diseases, acute or chronic inflammatory disorders (exacerbation of inflammation) for a period of 6 months before the study; no treatment with hormones, antibiotics and cytostatic drugs for a period of 6 months before the study. Exclusion criteria: failure Table 1. Characteristics of the studied population to meet any of the listed above criteria.

All the subjects were divided into several groups: individuals born in 1950-1960, individuals exposed in utero and postnatally, comparison group 1; individuals born until 1949 inclusive exposed only postnatally, comparison group 2. Comparison groups included patients living in similar economic and social environment with their postnatal absorbed dose to red bone marrow not exceeding 70 mGy [6]. Characteristics of the studied population are provided in Table 1.

Individuals exposed in utero and postnatally were significantly older compared to individuals of the comparison group 1 ( $p<0.001)$. It is worthy of note, however, that both groups were of similar age range (Table 1). No significant differences in ethnicity and gender were revealed (Table 1).

Hematopoietic stem cells (HSCs) and progenitor cells, expressing CD34 receptor on their surface, are primarily concentrated in the bone marrow. However, a small proportion of these cells (about 10\% of all HSCs present in human body) are also found in peripheral blood of healthy adult humans [7, 8]. In order to quantify CD34+ cells and immunocompetent cells, the $9 \mathrm{ml}$ samples of venous blood from the patients' cubital vein were collected in the fasting state using the vacuum tube with K3-EDTA (Greiner Bio-One; Austria). Quantification of CD34+ cells in peripheral blood of the subjects was performed by flow cytometry with the use of StemKit Reagents (Beckman Coulter; France) and Epics flow cytometer (Beckman Coulter; USA) in accordance with the manufacturer's instructions.

Statistical data processing was performed using SigmaPlot software (Systat Software Inc; USA). Mann-Whitney $U$ test was used to compare CD34+ cell counts in peripheral blood of patients from the studied groups. The differences were considered significant when $p<0.05$. The relationship between the peripheral blood $\mathrm{CD}_{3} 4^{+}$cell counts and the absorbed dose to red bone marrow, thymus, and peripheral lymphoid organs, or age, was defined using the Spearman's rankorder correlation; correlations were considered significant

\begin{tabular}{|c|c|c|c|c|c|}
\hline \multirow{2}{*}{\multicolumn{2}{|c|}{ Criteria }} & \multicolumn{2}{|c|}{ Individuals born in 1950-1960 } & \multicolumn{2}{|c|}{ Individuals born until 1949 inclusive } \\
\hline & & Comparison & Individuals exposed in utero and & Comparison & \\
\hline \multirow{2}{*}{$\begin{array}{l}\text { Ethnicity, } \\
\quad \%(n)\end{array}$} & Slavs & $62(37)$ & $52(14)$ & $32(6)$ & $45(21)$ \\
\hline & Turks & $38(23)$ & $\begin{array}{c}48(13) \\
p^{\star \star \star}=0,5\end{array}$ & $68(13)$ & $\begin{array}{c}55(26) \\
p^{\star \star \star}=0,5\end{array}$ \\
\hline \multirow[b]{2}{*}{ Gender, \% ( $(n)$} & Males & $40(24)$ & $30(8)$ & $37(7)$ & $21(10)$ \\
\hline & Females & $60(36)$ & $\begin{array}{c}70(19) \\
p^{\star \star \star \star}=0,5\end{array}$ & $63(12)$ & $\begin{array}{c}79(37) \\
p^{\star \star \star \star}=0,5\end{array}$ \\
\hline \multicolumn{2}{|c|}{$\begin{array}{l}\text { Average age, years, } \mathrm{M} \pm \mathrm{SE}^{\star \star} \\
\text { (min-max) }\end{array}$} & $\begin{array}{l}63,71 \pm 0,35 \\
(60-69)\end{array}$ & $\begin{array}{l}68,07 \pm 0,25 \\
(66-71) \\
p^{\star \star \star \star *}<0,001\end{array}$ & $\begin{array}{c}77,05 \pm 1,06 \\
(70-87)\end{array}$ & $\begin{array}{l}74,72 \pm 0,58 \\
(70-84) \\
p^{\star \star \star \star *}=0,06\end{array}$ \\
\hline \multicolumn{2}{|c|}{$\begin{array}{l}\text { Postnatal absorbed dose to red bone } \\
\text { marrow, } \mathrm{mGy}, \mathrm{M} \pm \mathrm{SE} \text { (min-max) }\end{array}$} & $\begin{array}{l}20 \pm 2 \\
(0-68)\end{array}$ & $\begin{array}{l}570 \pm 90 \\
(80-1720)\end{array}$ & $\begin{array}{c}10 \pm 4 \\
(0,4-50)\end{array}$ & $\begin{array}{l}790 \pm 90 \\
(80-2930)\end{array}$ \\
\hline \multicolumn{2}{|c|}{$\begin{array}{l}\text { Postnatal absorbed dose to thymus and } \\
\text { peripheral lymphoid organs, mGy, } \mathrm{M} \pm \mathrm{SE} \\
\text { (min-max) }\end{array}$} & $\begin{array}{c}0,9 \pm 0,2 \\
(0-8)\end{array}$ & $\begin{array}{l}80 \pm 20 \\
(2-430)\end{array}$ & $\begin{array}{c}8 \pm 2 \\
(0,08-30)\end{array}$ & $\begin{array}{c}110 \pm 10 \\
(8-370)\end{array}$ \\
\hline \multicolumn{2}{|c|}{$\begin{array}{l}\text { Fetal absorbed dose to red bone marrow, } \\
\qquad \mathrm{mGy}, \mathrm{M} \pm \mathrm{SE} \text { (min-max) }\end{array}$} & $\begin{array}{c}8 \pm 2 \\
(0,2-3)\end{array}$ & $\begin{array}{l}70 \pm 20 \\
(0-360)\end{array}$ & - & - \\
\hline \multicolumn{2}{|c|}{$\begin{array}{l}\text { Fetal absorbed dose to thymus and } \\
\text { peripheral lymphoid organs, mGy, } \mathrm{M} \pm \mathrm{SE} \\
\text { (min-max) }\end{array}$} & $\begin{array}{c}0,9 \pm 0,2 \\
(0-8)\end{array}$ & $\begin{array}{l}10 \pm 7 \\
(0-170)\end{array}$ & - & - \\
\hline
\end{tabular}

Note: ${ }^{*} n$ — studied population size; ${ }^{* *} \mathrm{M} \pm \mathrm{SE}$ — mean \pm standard error of the mean; ${ }^{* \star *}$ — significance level for intergroup differences in etnicity; $* * \star *$ significance level for intergroup differences in gender; ${ }^{* \star * \star}$ — significance level for intergroup differences in age. 
Table 2. Levels of $\mathrm{CD} 34^{+}$cells in peripheral blood of the subjects

\begin{tabular}{|c|c|c|c|}
\hline & Indicator & Absolute CD34+ cell counts, cells $/ \mu \mathrm{L}$ & Relative CD34+ cell counts, $\%$ \\
\hline \multirow{4}{*}{$\begin{array}{c}\mathrm{Me} \\
(25 \%-75 \%)\end{array}$} & Comparison group $1, n=60$ & $\begin{array}{l}37,00 \\
(24-64)\end{array}$ & $\begin{array}{c}0,04 \\
(0,03-0,07)\end{array}$ \\
\hline & Individuals exposed in utero and postnatally, $n=27$ & $\begin{array}{c}31,00 \\
(22-61) \\
p_{1}=0,32\end{array}$ & $\begin{array}{c}0,04 \\
(0,03-0,06) \\
p_{2}=0,67\end{array}$ \\
\hline & Comparison group $2, n=19$ & $\begin{array}{l}20,00 \\
(15-28)\end{array}$ & $\begin{array}{c}0,03 \\
(0,02-0,04)\end{array}$ \\
\hline & Individuals exposed only postnatally, $n=47$ & $\begin{array}{c}36,00 \\
(20-50) \\
p_{3}=0,004\end{array}$ & $\begin{array}{c}0,04 \\
(0,03-0,07) \\
p_{4}=0,009\end{array}$ \\
\hline
\end{tabular}

Note: Me - median; $p_{1}$ - significance level for differences in absolute CD34+ cell counts in the groups of individuals born in 1950-1960; $p_{2}-$ significance level for differences in relative CD34+ cell counts in the groups of individuals born in 1950-1960; $p_{3}$ - significance level for differences in absolute CD34 ${ }^{+}$cell counts in the groups of individuals born until 1949 inclusive; $p_{4}$ - significance level for differences in relative CD34+ cell counts in the groups of individuals born until 1949 inclusive.

when $p<0.05$. Qualitative features of the correlation were defined based on the correlation coefficients in accordance with the Chaddock scale.

\section{RESULTS}

No significant changes in absolute and relative peripheral blood $\mathrm{CD}_{3}{ }^{+}$cell counts were detected in individuals, exposed in utero and postnatally, compared to the 1st comparison group ( $p=0,32$ and $p=0,67$ respectively). However, in the group of individuals exposed only postnatally, a significant increase in peripheral blood CD34+ cell counts was observed compared to individuals from the $2^{\text {nd }}$ comparison group (Table 2) (significance level for differences in absolute CD34+ cell counts: $p=0.004$; significance level for differences in relative CD34+ cell counts: $p=0.009$ ).

In the group of individuals born in 1950-1960, there was a slight significant decline in absolute $\mathrm{CD} 4^{+}$cell counts in relation to postnatal absorbed dose to red bone marrow $(r=-0.24$; $p=0.03)$. Moreover, a slight significant decline in both absolute $(r=-0.26 ; p=0.02)$ and relative $(r=-0.23 ; p=0.03) \mathrm{CD}^{+} 4^{+}$ cell counts in peripheral blood in relation to postnatal absorbed dose to thymus and peripheral lymphoid organs was observed. No significant relationships between the studied parameters and fetal doses (significance level for fetal absorbed dose to red bone marrow and absolute $\mathrm{CD}_{34}{ }^{+}$cell counts: $p=0.94$; significance level for relative cell counts: $p=0.98$; significance level for fetal absorbed dose to thymus and peripheral lymphoid organs and absolute CD34+ cell counts: $p=0.48$; significance level for relative cell counts: $p=0.74)$. Regression analysis revealed no significant dose-dependent changes in peripheral blood CD34+ cell counts in individuals born in 1950-1960.

In the group of individuals born until 1949 inclusive, correlation analysis of dose-dependent changes in peripheral blood $\mathrm{CD}_{34}{ }^{+}$cell counts revealed a slight significant decline in both absolute $(r=0.29 ; p=0.02)$ and relative $(r=0.26 ; p=0.03)$ CD34+ cell counts in relation to postnatal absorbed dose to red bone marrow. No significant correlations between the CD34+ cell counts and postnatal absorbed dose to thymus and peripheral lymphoid organs were found (significance level for absolute HSC and progenitor cell counts: $p=0.14$; significance level for relative cell counts: $p=0.19$ ). Regression analysis revealed no significant relationships between $\mathrm{CD} 34^{+}$cell counts and postnatal absorbed dose to red bone marrow, thymus and peripheral lymphoid organs.

On order to define the relationship between CD34+ ${ }^{+}$cell counts and age, we decided to merge comparison group 1 (individuals born in 1950-1960) and comparison group 2 (individuals born until 1949 inclusive) for correlation analysis. In the joint comparison group, a slight significant decline in peripheral blood absolute $(r=-0.58 ; p<0.001)$ and relative $(r=-0.44 ; p<0.001) \mathrm{CD}^{+} 4^{+}$cell counts with age was observed. Correlation of blood HSC and progenitor cell counts with age in the joint comparison group was assessed with the use of
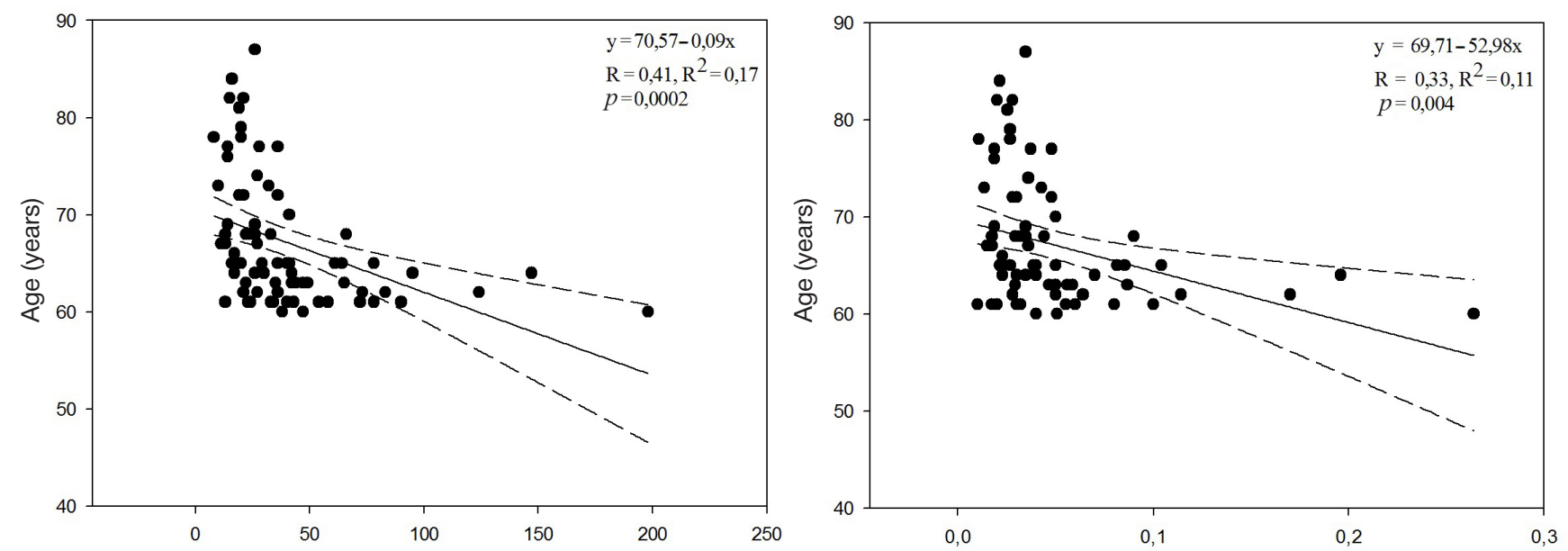

Absolute $\mathrm{CD} 34^{+}$cell counts (cells/ $/ \mathrm{L}$ )

Relative CD34+ cell counts (\%)

Fig. Correlation of peripheral blood $\mathrm{CD} 34^{+}$cell counts with age in individuals of joint comparison group 
regression analysis. Results of regression analysis of agerelated changes in peripheral blood absolute and relative $\mathrm{CD}^{+} 4^{+}$ cell counts in individuals from the joint comparison group are presented in Fig.

In the group of individuals exposed in utero and postnatally, no significant correlation of peripheral blood absolute $(p=0.14)$ and relative $(p=0.36)$ CD34 $4^{+}$cell counts with age was observed at the time of the study.

In the group of individuals exposed only postnatally, there was a significant decline in peripheral blood CD34+ cell counts with age at the time of the study (significance level for absolute counts: $p=0.02(r=-0.33)$; significance level for relative counts: $p=0.04(r=-0.29))$. Regression analysis revealed no significant correlation of peripheral blood HSC and progenitor cell counts with age in individuals exposed only postnatally.

\section{DISCUSSION}

Currently, there are no reliable data on the condition of HSC pool over a long time following chronic exposure to radiation. However, there is evidence obtained during experiments on mice, which demonstrates the following late effects of radiation exposure: permanent phenotypic change in the population of red bone marrow HSCs [10], increased levels of apoptosis in HSCs, as well as accumulation of DNA damage in HSCs and progenitor cells [10-12]. The observed effects are believed to result from asymmetric division of HSCs in the bone marrow: one daughter cell remains a stem cell retaining genomic alterations resulting from the parent cell radiation exposure, together with the bystander effect, observed during the experiment involving transplantation of exposed and non-exposed murine HSCs [12]. Functional failure in HSCs and progenitor cells over a longterm period could be a result of all listed above late effects of radiation exposure.

The paper reports preliminary results of the peripheral blood HSC pool and progenitor cell assessment in chronically exposed residents of the villages located along the Techa River over a long-term period after the onset of exposure. Peripheral blood CD34 ${ }^{+}$cell counts were defined in chronically exposed individuals 60 years after the beginning of the exposure against a background of involution changes. Earlier, high levels of unstable chromosome aberrations in peripheral blood lymphocytes, which could not be explained by the dose from current exposure, were observed in residents of the villages located along the Techa River during assessment, performed over a long-term period [13]

The detected dose-dependent decline in peripheral blood $\mathrm{CD} 4^{+}$cell counts in individuals, exposed in utero and postnatally, could be due to radiation-induced damage to the HSC pool precisely during the period of embryonic development, being the most sensitive to ionizing radiation exposure [14]. Meanwhile, lack of age-related changes in peripheral blood HSC and progenitor cell counts in this group could be explained by age range of individuals, exposed in utero and postnatally, inadequate (five years only) for establishing the relationship. It should be noted that in the group of individuals exposed only postnatally, there was a negative correlation between the CD34+ cell counts and the subjects' age. Agerelated decline in $\mathrm{CD}_{34}{ }^{+}$cell counts in the group of individuals exposed only postnatally does not conflict with the literary evidence. Literature sources report reduced pool of HSCs and progenitor cells in peripheral blood of Japanese Hiroshima atomic bomb survivors [7, 9, 15].

Old age of exposed individuals creates a burden on the body. Thus, age-related alterations in HSC and progenitor cell metabolism have been shown [16], resulting in cellular adaptation deterioration. Such involution processes occurring against a background of chronic exposure make it possible to register effects of HSC pool and progenitor cell deficits over a long time after chronic radiation exposure.

Furthermore, in the group of individuals exposed only postnatally, there was a positive correlation between the HSC and progenitor cell counts and postnatal absorbed dose to red bone marrow; these indicator values were higher compared to the $2^{\text {nd }}$ comparison group. However, alterations in peripheral blood cell composition, i.e. low neutrophil and lymphocyte counts, are registered in individuals exposed only postnatally even 60 and more years after the onset of chronic radiation exposure [3]. Thus, our findings may reflect activation of compensatory mechanisms, enabling continuous proliferation of HSCs and progenitor cells in response to the listed above alterations.

The resulting data on dose-dependent changes in peripheral blood CD34+ cell counts of chronically exposed individuals differ from the previously published data [16], showing no dose-dependent changes in peripheral blood HSC and progenitor cell counts of the ageing cohort of Hiroshima atomic bomb survivors. This fact could be due to the nature of radiation exposure: residents of the villages located along the Techa River were exposed mainly to chronic ${ }^{90} \mathrm{Sr}$ contamination, affecting precisely haematopoietic areas of red bone marrow.

\section{CONCLUSIONS}

The study shows increased hematopoietic stem cell (HSC) pool size and progenitor cells in peripheral blood of individuals exposed postnatally. The group of individuals exposed in utero and postnatally was comparable to comparison group 1 based on peripheral blood $\mathrm{CD}^{+} 4^{+}$cell counts. Slight significant correlations of $\mathrm{CD}_{3} 4^{+}$cell counts with the dose have been defined in the groups of individuals exposed in utero and postnatally, and individuals exposed only postnatally. However, the correlations were multidirectional: peripheral blood HSC and progenitor cell counts in individuals exposed in utero and postnatally dose dependently decrease; blood HSC and progenitor cell counts in individuals exposed only postnatally dose dependently increase. The results obtained are preliminary. Further research will make it possible to acquire more reliable data on the impact of low-intensity irradiation of red bone marrow on the number of HSCs and progenitor cells over a long time after chronic radiation exposure.

\section{References}

1. Akleyev AV, et al., editors. Consequences of radioactive contamination of the Techa River. Federal Medical and Biological Agency, Ural Research Center for Radiation Medicine. Chelyabinsk, 2016; 390 p. Russian.
2. ICRP Statement on tissue reactions. Early and late effects of radiation in normal tissues and organs - threshold doses for tissue reactions in a radiation protection context. ICRP Publication 118. Ann ICRP. 2012; 41 (1/2); 322 p. 
3. Akleyev AA. Immune status of a man long after chronic radiation exposure. medical radiology and radiation safety. 2020; 65 (4): 29-35. DOI: 10.12737/1024-6177-2020-65-4-29-35. Russian.

4. Varfolomeyeva TA, Akleyev AA, Mandrykina AS. The characteristics of homeostasis in individuals chronically exposed to radiation in the South Urals at late time after exposure. Medical Radiology and Radiation Safety. 2016; 61 (2): 39-45. Russian.

5. Degteva MO, Napier BA, Tolstykh El, Shishkina EA, Bougrov NG, Krestinina LYu, Akleyev AV. Individual dose distribution in cohort of people exposed as a result of radioactive contamination of the Techa river. Medical Radiology and Radiation Safety. 2019; 64 (3) 46-53. DOI: 10.12737/article_5cf2364cb49523.98590475. Russian.

6. SanPin 2.6.1.2523-09 "Standards of radiation safety (NRB 99/2009)". M., 2009; 225p.

7. Kato K, Omori A, Kashiwakura I. Radiosensitivity of human haematopoietic stem/progenitor cells. J Radiol Prot. 2013; 33 (1) 71-80. DOI:10.1088/0952-4746/33/1/71

8. Mauch P, Constine L, Greenberger J, et al. Hematopoietic stem cell compartment: acute and late effects of radiation therapy and chemotherapy. Int J Radiat Oncol Biol Phys. 1995; 31 (5): 1319 39. DOI: 10.1016/0360-3016(94)00430-S.

9. Kato K, Kuwabara M, Kashiwakura I. The influence of gender- and age-related differences in the radiosensitivity of hematopoietic progenitor cells detected in steady-state human peripheral blood. J Radiat Res. 2011; 52 (3): 293-9. DOI: 10.1269/jrr.10142.

10. Simonnet AJ, Nehmé J, Vaigot P, Barroca V, Leboulch P, TronikLe Roux D. Phenotypic and functional changes induced in

\section{Литература}

1. Аклеев А. В. и др., редакторы. Последствия радиоактивного загрязнения реки Течи. Федеральное медико-биологическое агентство, Уральский научно-практический центр радиационной медицины.Челябинск, 2016; 390 с.

2. ICRP Statement on tissue reactions. Early and late effects of radiation in normal tissues and organs - threshold doses for tissue reactions in a radiation protection context. ICRP Publication 118. Ann ICRP. 2012; 41 (1/2); 322 p.

3. Аклеев А. А. Иммунный статус человека в отдаленном периоде хронического радиационного воздействия. Медицинская радиология и радиационная безопасность. 2020; 65 (4): 2935. DOI: 10.12737/1024-6177-2020-65-4-29-35.

4. Варфоломеева Т. А., Аклеев А. А., Мандрыкина А. С. Показатели гомеостаза в отдаленном периоде у лиц, подвергшихся хроническому облучению на Южном Урале. Медицинская радиология и радиационная безопасность. 2016; 61 (2): 39-45.

5. Дегтева М. О., Напье Б.А., Толстых Е.И., Шишкина Е. А., Бугров Н. Г., Крестинина Л. Ю., Аклеев А. В. Распределение индивидуальных доз в когорте людей, облученных в результате радиоактивного загрязнения реки Течи. Медицинская радиология и радиационная безопасность. 2019; 64 (3): 4653. DOI: $10.12737 /$ article 5cf2364cb49523.98590475.

6. СанПин 2.6.1.2523-09 «Нормы радиационной безопасности (HРБ - 99/2009)». М., 2009; 225 C.

7. Kato K, Omori A, Kashiwakura I. Radiosensitivity of human haematopoietic stem/progenitor cells. J Radiol Prot. 2013; 33 (1): 71-80. DOI:10.1088/0952-4746/33/1/71

8. Mauch P, Constine L, Greenberger J, et al. Hematopoietic stem cell compartment: acute and late effects of radiation therapy and chemotherapy. Int J Radiat Oncol Biol Phys. 1995; 31 (5): 1319-39. DOI: 10.1016/0360-3016(94)00430-S. hematopoietic stem/progenitor cells after gamma-ray radiation exposure. Stem Cells. 2009; 27 (6): 1400-9. DOI: 10.1002/ stem.66.

11. Lorimore SA, Wright EG. Radiation-induced genomic instability and bystander effects: related inflammatory-type responses to radiation-induced stress and injury? A review. Int J Radiat Biol. 2003; 79 (1): 15-25.

12. Harfouche G, Martin MT. Response of normal stem cells to ionizing radiation: a balance between homeostasis and genomic stability. Mutat Res. 2010; 704 (1-3): 167-74. DOI: 10.1016/j. mrrev.2010.01.007.

13. Vozilova AV, Shagina NB, Degteva MO, Akleyev AV. Chronic radioisotope effects on residents of the Techa river (Russia) region: Cytogenetic analysis more than 50 years after onset of exposure. Mutation Research/Genetic Toxicology and Environmental Mutagenesis. 2013; 756 (1-2): 115-18. DOI: 10.1016/j.mrgentox.2013.05.016.

14. Barber RC, Hardwick RJ, Shanks ME, et al. The effects of in utero irradiation on mutation induction and transgenerational instability in mice. Mutat Res. 2009; 664: 6-12. DOI: 10.1016/j. mrfmmm.2009.01.011.

15. Vorotelyak EA, Vasiliev AV, Terskikh W. The problem of stem cell definition. Cytology. 2019; 61 (1): 3-15. DOI: 10.1134/ S0041377119010073.

16. Kyoizumi S, Kubo Y, Misumi M, et al. Circulating hematopoietic stem and progenitor cells in aging atomic bomb survivors. Radiat Res. 2016; 185 (1): 69-76. DOI:10.1667/RR14209.1.

9. Kato K, Kuwabara M, Kashiwakura I. The influence of gender- and age-related differences in the radiosensitivity of hematopoietic progenitor cells detected in steady-state human peripheral blood. J Radiat Res. 2011; 52 (3): 293-9. DOI: 10.1269/jrr.10142.

10. Simonnet AJ, Nehmé J, Vaigot P, Barroca V, Leboulch P, TronikLe Roux D. Phenotypic and functional changes induced in hematopoietic stem/progenitor cells after gamma-ray radiation exposure. Stem Cells. 2009; 27 (6): 1400-9. DOl: 10.1002/stem.66.

11. Lorimore SA, Wright EG. Radiation-induced genomic instability and bystander effects: related inflammatory-type responses to radiation-induced stress and injury? A review. Int $\mathrm{J}$ Radiat Biol. 2003; 79 (1): 15-25.

12. Harfouche G, Martin MT. Response of normal stem cells to ionizing radiation: a balance between homeostasis and genomic stability. Mutat Res. 2010; 704 (1-3): 167-74. DOI: 10.1016/j. mrrev.2010.01.007

13. Vozilova AV, Shagina NB, Degteva MO, Akleyev AV. Chronic radioisotope effects on residents of the Techa river (Russia) region: Cytogenetic analysis more than 50 years after onset of exposure. Mutation Research/Genetic Toxicology and Environmental Mutagenesis. 2013; 756 (1-2): 115-18. DOI: 10.1016/j.mrgentox.2013.05.016.

14. Barber RC, Hardwick RJ, Shanks ME, et al. The effects of in utero irradiation on mutation induction and transgenerational instability in mice. Mutat Res. 2009; 664: 6-12. DOI: 10.1016/j. mrfmmm.2009.01.011.

15. Воротеляк Е. А., Васильев А. В., Терских В. В. Проблема дефиниции стволовой клетки. Цитология. 2019; 61 (1): 3-15. DOI: 10.1134/S0041377119010073.

16. Kyoizumi S, Kubo Y, Misumi M, et al. Circulating hematopoietic stem and progenitor cells in aging atomic bomb survivors. Radiat Res. 2016; 185 (1): 69-76. DOI:10.1667/RR14209.1. 